\title{
En mann i 40-årene med hevelse i begge øyehuler
}

En mann i 40-årene ble innlagt i revmatologisk avdeling med mistanke om systemsykdom. Han hadde i lengre tid hatt symptomer fra øynene, men utredning viste at flere organer var affisert.

Mannen ble henvist til revmatolog med mistanke om systemsykdom. Han hadde i flere måneder hatt plager med smerter, hevelse rundt øynene, følelse av utstående øyne og avtakende visus. Ved cerebral MR var det påvist en kontrastoppladende ekspansiv lesjon retrobulbært $i$ høyre øyehule og en tilsvarende, men mindre lesjon på venstre side. Det var tatt biopsi, og under prøvetakingen var det observert at synsnerven lå innleiret i en fast og lite vaskularisert tumor. Det lot seg derfor ikke gjøre å fjerne hele tumoren.

Histologisk undersøkelse hadde vist inflammatorisk prosess med mange makrofager, spredtliggende og enkelte grupper av lymfoide celler, spredte plasmaceller, nøytrofile og eosinofile granulocytter (fig 1). Atypiske celler, granulomatøs betennelse eller vaskulitt var ikke påvist. Spesialfarging for sopp, bakterier og mykobakterier var negativ. Ved rutinemessig immunhistokjemisk undersøkelse var makrofagene posi-

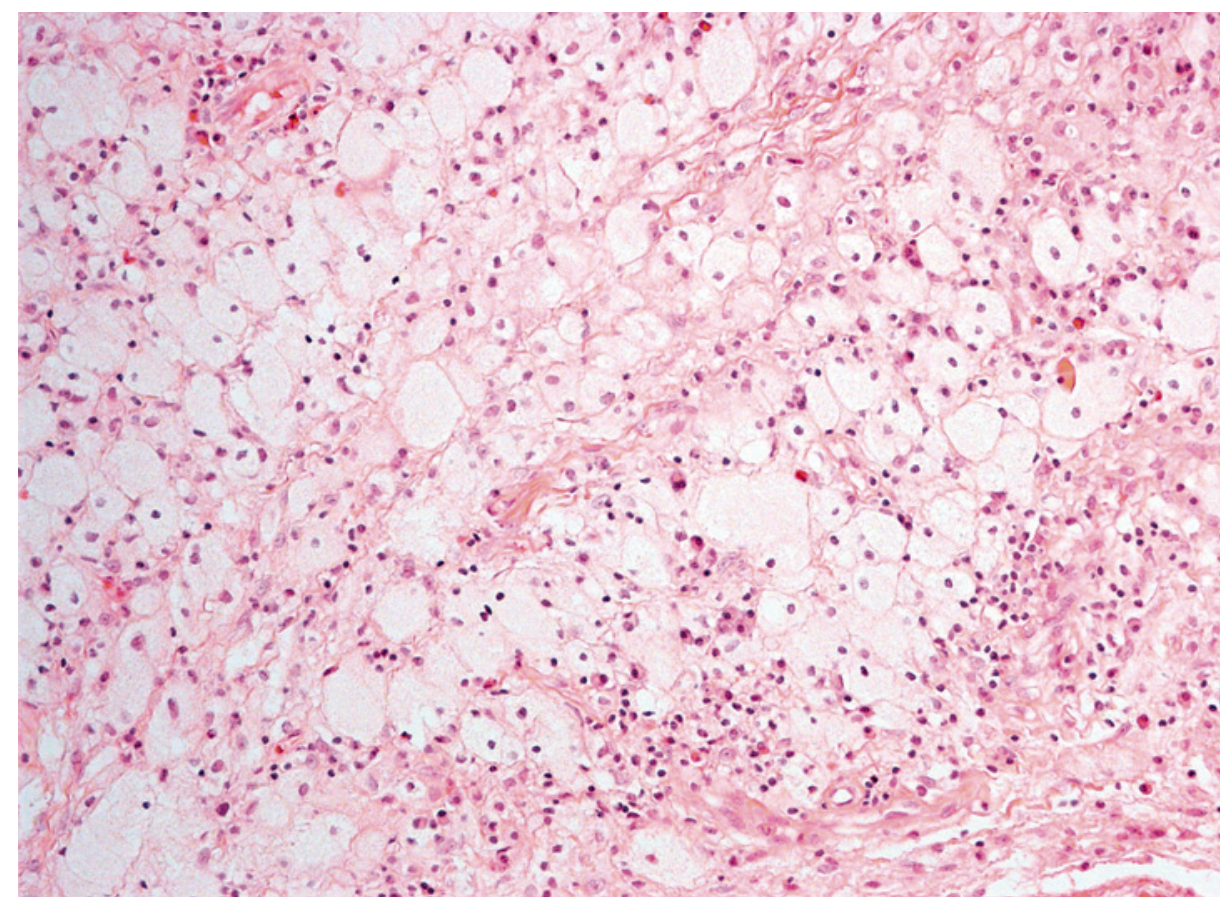

Figur 1 HE-farget snitt viser de typiske makrofagene med rikelig skummende cytoplasma (skummakrofager). Innimellom er det noen små lymfoide celler, plasmaceller og enkelte eosinofile granulocytter
Øyvind Midtvedt

omidtved@ous-hf.no

Jan Tore Gran

Revmatologisk avdeling

Hanne Solheim

\section{Eva Kirkhus}

Avdeling for radiologi og nukleærmedisin

tive for CD68. De små lymfoide cellene var $B$-celler positive for CD20 samt T-celler positive for CD4 og CD8.

Man fant ingen holdepunkter for malign eller infeksiøs sykdom i preparatet, og tilstanden ble initialt oppfattet som idiopatisk pseudotumor i orbita (1). Dette er en godartet, betennelsesaktig tilstand av ukjent årsak, som vanligvis responderer godt på behandling med kortikosteroider (2). Det ble derfor startet med prednisolon $100 \mathrm{mg}$ daglig, med avtale om gradvis dosereduksjon.

Pasienten hadde imidlertid økende plager en følelse av å ha utstående øyne og avtakende visus - på tross av prednisolonbehandlingen. I et forsøk på å redusere omfanget av oppfyllingen ble det gitt strålebehandling (2 Gy $\times 15$ ) i tillegg til prednisolon $20 \mathrm{mg}$ daglig (3). Etter strålebehandlingen var det likevel uendret synssvekkelse, vedvarende exophthalmus på høyre side og ingen til-

\section{Oslo universitetssykehus, Rikshospitalet}

\section{Signe Spetalen}

Avdeling for patologi

Oslo universitetssykehus, Radiumhospitalet 

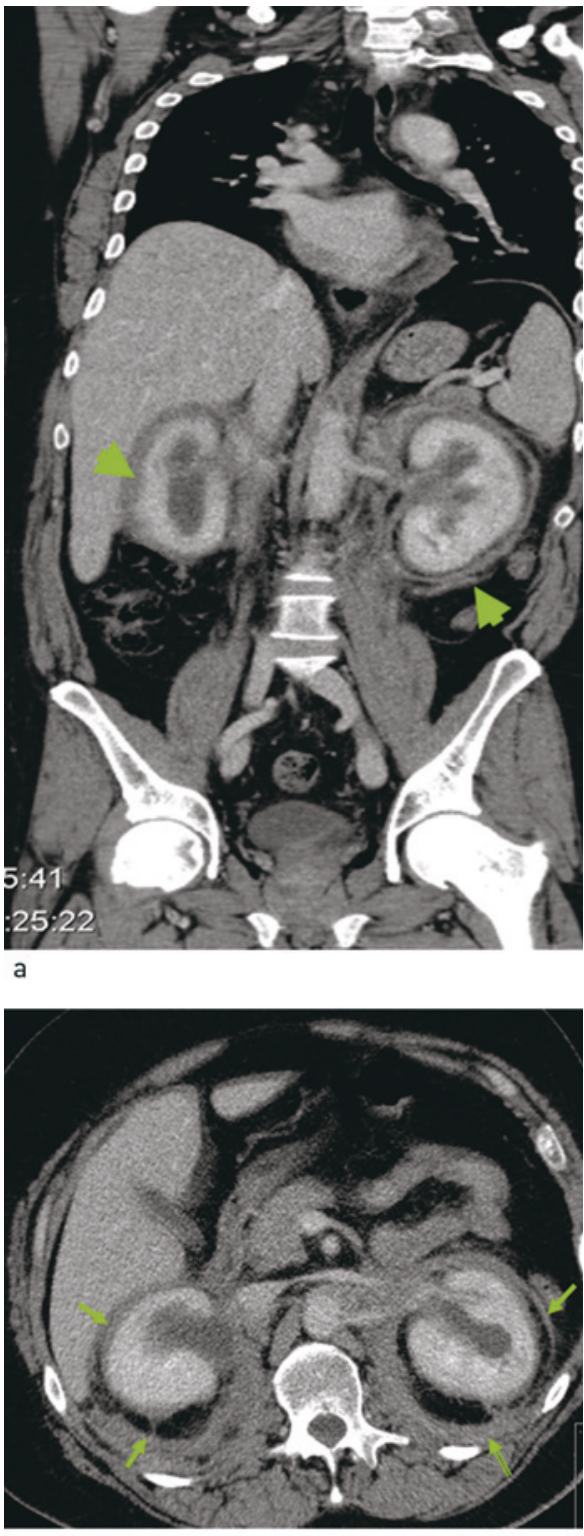

Figur 2 CT abdomen med «hairy kidneys». al frontalsnitt, b) tverrsnitt

bakegang av forandringene $i$ orbitae på cerebral MR. Pasienten ble etter noen uker innlagt $i$ øyeavdeling med økende smerter rundt høyre øye, redusert syn, tåkesyn, følelse av mer utstående øye samt kvalme, oppkast og diaré. Han hadde på dette tidspunktet måttet seponere predniosolon på grunn av betydelige bivirkninger.

Ved innleggelsen ble tatt en rekke blodprøver. De viste blant annet senkningsreaksjon på $91 \mathrm{~mm} / \mathrm{t}(<15 \mathrm{~mm} / \mathrm{t})$, CRP $132 \mathrm{~g} / \mathrm{l}$ $1<5 \mathrm{~g} / \mathrm{ll}$, negative tester for hiv, hepatitt $B$ og hepatitt $C$, treponema, borrelia-IgM, ANA (antinukleære antistoffer) og IGRA (Interferon-Gamma Release Assay), det var ingen vekst i blodkultur og normal thyreoideastatus. Det ble funnet svakt positiv MPO-ANCA Imyeloperoksidase - antinøytrofilt cytoplas- maantistoff) på $26 \mathrm{IU} / \mathrm{ml}(<7 \mathrm{IU} / \mathrm{ml}$, men test for P-ANCA var negativ. Videre ble det påvist en monoklonal komponent i gammasonen (IgG-kappa omkring $1 \mathrm{~g} / \mathrm{l}$. Ny cerebral MR viste uendrede funn med bilaterale orbitale tumorer. Utredningen hadde så langt ikke gitt diagnostisk avklaring, men på grunn av positiv MPO-ANCA ble pasienten henvist til revmatolog.

Tilstedeværelse av positiv MPO-ANCA med negativ P-ANCA er et uspesifikt funn og kan forekomme ved en rekke inflammatoriske og immunologiske tilstander. Positiv MPO- og P-ANCA er særlig assosiert med mikroskopisk polyangiitt, men fraværet av tegn på interstitiell lungesykdom, glomerulonefritt og perifer nevropati gjorde denne diagnosen lite sannsynlig.

Ved annen ANCA-assosiert sykdom, slik som granulomatose med polyangiitt (Wegeners granulomatose) eller eosinofil granulomatose med polyangiitt (Churg-Strauss' vaskulitt), ses ofte tilbakevendende betennelser i øvre og nedre luftveier, astma eller allergi, men heller ikke dette hadde vår pasient hatt. Grunnet funnet av en monoklonal komponent ble han vurdert av hematolog. Det ble ikke funnet holdepunkter for malign hematologisk sykdom.

Videre var det normal serum-lgG4-subklasse på 0,63 g/l (0,03-1,35 g/l). Serumkonsentrasjonen av IgG4 er ofte forhøyet ved IgG4-relatert sykdom, men kan være normal. Undersøkelse av tidligere biopsimateriale ga ingen holdepunkter for lgG4-relatert sykdom. Ny gransking av tidligere biopsimateriale ga heller ingen holdepunkter for sarkoidose, malignitet, infeksjon eller endokrin oftalmoplegi.

Det ble gjort en ny biopsi av tumor, og peroperativt ble det funnet en hard, uregelmessig og gulaktig tumor. Tumormassene var infiltrert $i$ orbita og $n$. opticus var innleiret tumor, som ved første biopsitaking. Revmatologen kunne ikke utelukke bakenforliggende systemsykdom, og pasienten ble innlagt $i$ revmatologisk avdeling.

Ved innleggelsen var pasienten i god allmenntilstand. Han var afebril og hadde ikke utslett eller perifere artritter, og pulsen a. radialis var sidelik og normal. Blodtrykket var 180/101 mm Hg, pulsen $115 \mathrm{slag} / \mathrm{min}$.

CT thorax og abdomen viste bløtdelsoppfylling langs aorta i flere nivåer, og i nedre del omkranset vevsfortykkelsen hele aorta. Fra nivå med nedre nyrepol og til bifurkaturen var det utbredelse som ved retroperitoneal fibrose med fortykket perirenale fascie. Innenfor perirenalt fettvev var også begge nyrekapsler fortykket med forandringer vel forenlig med «hairy kidneys» (fig 2). Begge nyrebekkener var dilatert, uten utvidelse av ureter.

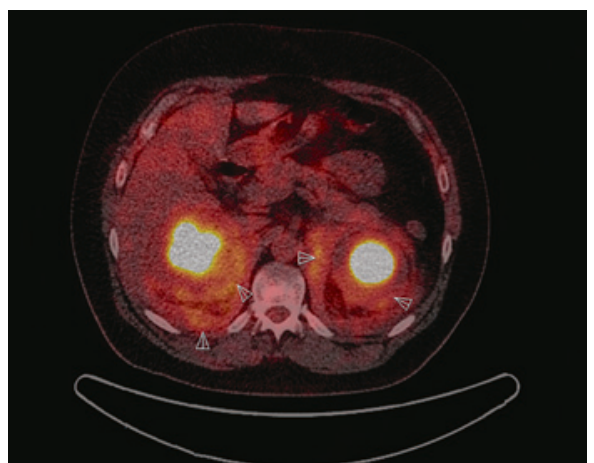

Figur 3 18FDG PET-skann viser økt opptak i perirenalt vev og «hairy kidneys»

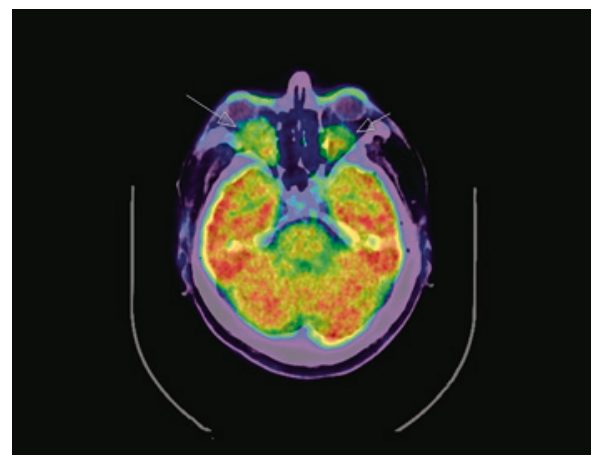

Figur 4 Retrobullære oppfyllinger i 18FDG PET-CT

Funn av sykelige prosesser rundt aorta, nyrer og i øyehuler ga sikre holdepunkter for multiorgansykdom, men noen endelig diagnose kunne ikke stilles. Det ble derfor besluttet å foreta en omfattende kartlegging av sykdommens utbredelse.

18FDG PET-CT viste økt opptak perirenalt, oppfyllinger $i$ begge orbitae, periaortalt, $i$ myokard og i oppfylling rundt hjertet samt $i$ beinmargen i distale deler av begge femora og proksimale tibiae (fig 3, fig 4). I nyrene var det dilatasjon av calyces, men ikke dilatasjon av det ekstrarenale nyrebekken eller uretre. Ultralyddoppler av nyrearterier viste ikke tegn på nyrearteriestenose. I lungene var det lette mattglassfortetninger og sparsom bilateral pleuraeffusjon. Spirometri viste lett redusert belgfunksjon av restriktiv type. Ekkokardiografi viste grensestor venstre ventrikkel med god venstre og høyre ventrikkelfunksjon, i tillegg til lett perikardvæskebrem på 0,5-0,6 cm uten hemodynamisk betydning.

Røntgenundersøkelse av de lange rørknoklene viste symmetrisk utbredt sklerose $i$ diafyser og metafyser, med utsparing av epifysene i radius, ulna, femur og tibia (fig 5). I tillegg var det tegn til periostitt, mest uttalt i femur og i tibia. Ved skjelettscintigrafi var det kraftig aktivitetsopptak i distale del av femur, proksimale og distale del av tibia, 


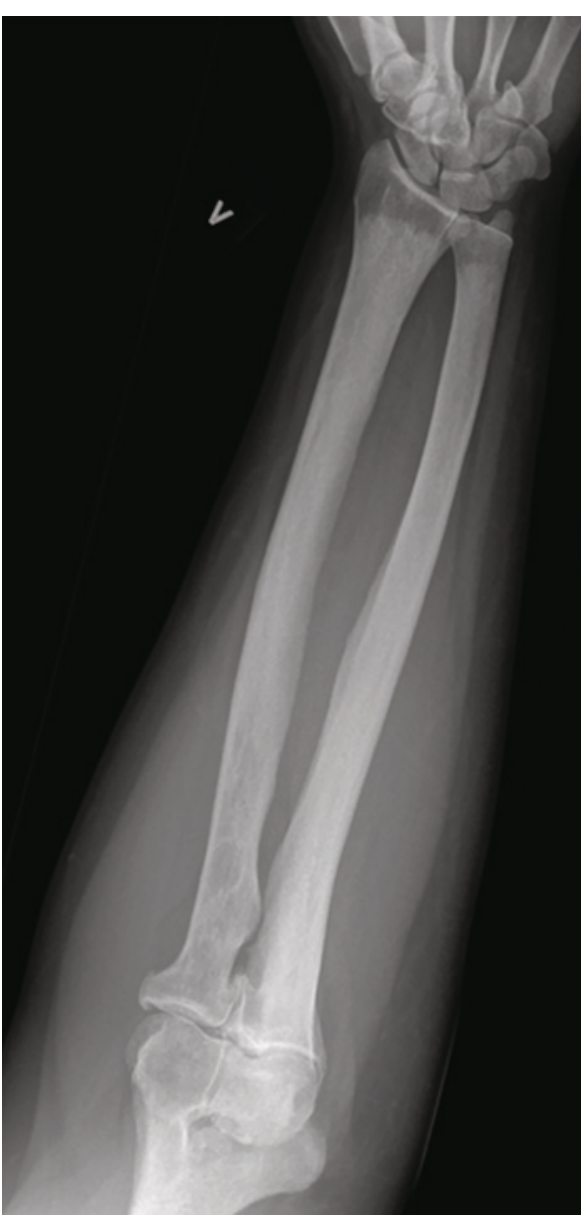

Figur $\mathbf{5}$ Symmetrisk utbredt sklerose i diafyser og metafyser og utsparing av epifysene i radius og ulna

distale del av radius og i maksillen bilateralt (fig 6). Endokrinolog fant ikke holdepunkter for diabetes insipidus eller andre endokrine forstyrrelser.

Pasientens multiorgansykdom affiserte vevet i øyehulene, aorta, perikard, perirenale områder og de lange rørknoklene. Erdheim-Chesters sykdom ble mistenkt, og det ble bedt om ny gransking av biopsiene fra orbita.

Ved ny gransking ble det poengtert at makrofagene hadde rikelig med lyst skummende cytoplasma, forenlig med skummakrofager. Immunfenotyping viste at de CD68-positive makrofagene var negative for CD1a og 5100 . Patolog konkluderte med at det morfologiske bildet passet med Erdheim-Chesters sykdom.

Den nye granskingen av biopsimaterialet sammenholdt med det kliniske bildet førte til at vi konkluderte med Erdheim-Chesters sykdom, en sjelden form for histiocytose med affeksjon av en rekke organer. Det ble derfor startet behandling med pegylert interferon- $\alpha$.

\section{Diskusjon}

Erdheim-Chesters sykdom er en sjelden ikke-langerhanscelleform for histiocytose av ukjent etiologi. Sykdommen ble beskrevet første gang av Jakob Erdheims elev Wiliam Chester i 1930 (4). Histiocytose er en gruppebetegnelse på en rekke sykdommer som histologisk karakteriseres av infiltrasjon og akkumulering av monocytter, makrofager og dendrittiske celler i affisert vev.

Ved immunhistokjemiske undersøkelser finner man ved Erdheim-Chesters sykdom CD68-positive og CD1a-negative histiocytter, mens man ved langerhanscellehistiocytose påviser CDla-positive histiocytter. I de fleste tilfellene av Erdheim-Chesters sykdom $(80 \%)$ er farging for S100-protein negativ. Diagnosen Erdheim-Chesters sykdom settes ut fra en kombinasjon av kliniske, bildediagnostiske og histologiske funn.

Sykdommen rammer menn hyppigere enn kvinner, og gjennomsnittlig debutalder er 55 år (16-80 år) (5). Mange organer kan bli affisert av sykdommen (tab 1) $(5,6)$. Nesten alle pasienter med Erdheim-Chesters sykdom har affeksjon av skjelettet, men bare omkring halvparten har symptomer på dette og da som oftest som smerter i knær og ankler. Typiske radiologiske funn er bilateral og symmetrisk osteosklerose i diafysen og metafysen til de lange rørknoklene, oftest i underekstremitetene. 99technetiumskjelettscintigrafi og 18FDG PET-skann vil vise økt opptak i disse områdene (7-9).

Til forskjell fra langerhanscellehistiocytose ser man vanligvis ikke affeksjon av det aksiale skjelettet ved Erdheim-Chesters sykdom (7). Ved langerhanscellehistiocytose er det som regel osteolytiske lesjoner i skjelettet og sjelden affeksjon av de lange rørknoklene (7). Vår pasient hadde typiske funn i skjelettet, påvist ved både scintigrafi, røntgenundersøkelse og PET-skann.

Erdheim-Chesters sykdom er en kronisk lidelse hvor forløp og sykdomsutfall er avhengig av hvilke organer som er affisert. Oftest ses et sykdomsforløp med affeksjon av flere organer over tid, uten spontan remisjon. Før oppstart og valg av medikamentell behandling er det nødvendig med en bred utredning for å kartlegge hvilke organer som er affisert. Både røntgen-, CT- og MRundersøkelse kan vise sykdomsaffeksjon, men for vurdering av sykdomsaktivitet og evaluering av terapirespons er PET-skann angitt å være et godt hjelpemiddel (8).

Ved hjerteaffeksjon affiseres perikard hyppig, det kan føre til komplikasjoner som hjertetamponade (10). Ved aortaaffeksjon ses oftest sirkumferensiell infiltrasjon rundt torakal- og/eller abdominalaorta. Dette har fătt betegnelsen «coated aorta» (5) og ble funnet hos vår pasient. Infiltrasjonen rundt

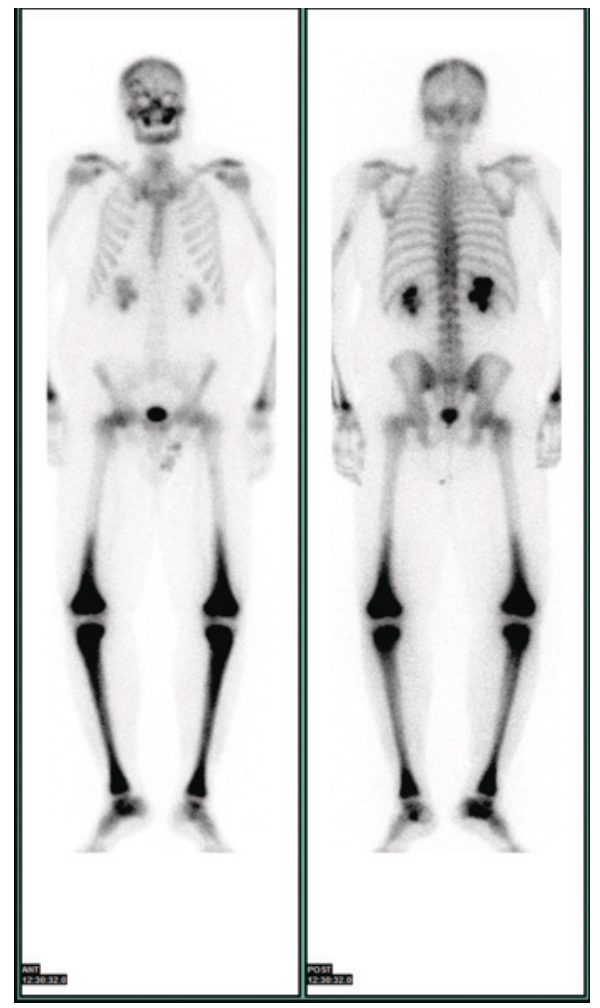

Figur 6 Økt opptak i lange rørknokler på skjelettscintigrafi

aorta ved Erdheim-Chesters sykdom rammer også den bakre del av aorta, mens ved idiopatisk retroperiotoneal fibrose, som vi først mistenkte at pasienten hadde, affiseres som regel bare den fremre og laterale del av aorta. Infiltrasjonen rundt aorta kan spre seg til større avgangskar og medføre stenoser.

Et karakteristisk funn ved Erdheim-Chesters sykdom er infiltrasjon av perirenalt vev, som på CT kan ses som «hairy kidneys». Dette kan påvises hos opptil $68 \%$ av pasientene (5), og ble også funnet hos vår pasient.

Pleura og lungeparenkym kan også angripes ved Erdheim-Chesters sykdom (11) og gir symptomer som dyspné og hoste. Vår pasient hadde mattglassforandringer ved HRCT-undersøkelse (High Resolution Computed Tomography), men ingen uttalte lungesymptomer. Til forskjell fra sarkoidose vil man som regel ikke se mediastinal lymfadenopati ved Erdheim-Chesters sykdom (12). Progredierende lungesykdom med respirasjonssvikt er sjelden.

Videre kan man se infiltrasjon av hypofysen, med påfølgende endokrine forstyrrelser, hos opptil $25 \%$ av pasientene, og hudmanifestasjoner med xantelasmer på øyelokk opptrer hos $28 \%$ (5).

De dominerende manifestasjonene hos vår pasient var smerter og hevelse $\mathrm{i}$ begge øyehuler. Infiltrasjon i orbita er beskrevet hos opptil $25 \%$ av pasientene (13). Infiltrasjonen kan bli massiv, er ofte refraktær over- 
Tabell 1 Kliniske og radiologiske funn ved Erdheim-Chesters sykdom, etter Haroche og medarbeidere (5) og Arnaud og medarbeidere (6)

$\begin{array}{lcc}\text { Kliniske og radiologiske funn } & \text { Andel funn (\%) } & \text { Hos pasienten } \\ \text { Patologiske funn i skjelett ved røntgen eller scintigrafi } & 95 & \text { Til stede } \\ \text { Skjelettsmerter } & 50 & \text { Til stede } \\ \text { Retroorbital infiltrasjon } & 25 & \text { Til stede } \\ \text { Periaortal infiltrasjon (coated aorta) } & 30 & \text { Til stede } \\ \text { «Hairy kidneys» } & 68 & \text { Til stede } \\ \text { Perikard } & 45 & \text { Til stede } \\ \text { Lunge } & 22-54 & \text { Til stede } \\ \text { Diabetes insipidus } & 27 & \text { Ikke til stede } \\ \text { Xantelasmer } & 19 & \text { Ikke til stede } \\ \text { Sentralnervesystemet } & 15-51 & \text { Ikke til stede }\end{array}$

for medikamentell behandling og kan kreve kirurgisk behandling.

Patogenesen til Erdheim-Chesters sykdom er ikke kjent, og det er uklart om sykdommen skal klassifiseres som en reaktiv inflammatorisk eller en malign neoplastisk prosess $(14,15)$. Det er funnet høye nivåer av proinflammatoriske cytokiner som interferon- $\alpha$, IL-7, IL-12 og MCP-1 og nedsatt IL-4 (6). Høye nivåer av IL-1, IL-6, RANKL (reseptoraktivator av nukleær faktor kappaB) og oppregulering av platederivert vekst faktor i de histiocyttiske infiltratene er også beskrevet (16). Dette styrker hypotesen om at sykdommen forårsakes av en forstyrret immunologisk reaksjon med overvekt av Th1-respons. Det er nylig vist at mange pasienter med Erdheim-Chesters sykdom har en mutasjon i BRAF V600-genet (17). BRAF er et protein i MAPK-signalveien (mitogenaktivert proteinkinase) som er viktig for regulering av celledeling, og aktiverte $B R A F$ V600-mutasjoner finnes i varierende grad ved flere kreftformer.

Standardbehandlingen av Erdheim-Chesters sykdom har vært perorale kortikosteroider. Det er imidlertid bare halvparten av pasientene som har effekt av dette (7), og hos vår pasient ble det ikke registret noen behandlingsgevinst. Hos pasienter som ikke responderer på kortikosteroider kan interferon- $\alpha$ forsøkes $(18-20)$. Det gir stabilisering eller bedring av sykdommen hos omkring to tredeler av pasientene (20). Behandlingseffekten kommer imidlertid ofte sent, og hos nærmere en tredel ser man effekt først etter 12 måneders behandling.

I tillegg er det vist at behandling med interferon- $\alpha$ er en uavhengig faktor for bedret overlevelse (21). Pegylert interferon- $\alpha$ tolereres ofte bedre enn interferon- $\alpha$ og er angitt til å være førstevalg ved Erdheim-Chesters sykdom med alvorlig organaffeksjon (5). Av andre medikamenter er det rapportert effekt av tyrosinkinasehemmeren imatinibmesylat, interleukin-1-reseptorantagonisten anakinra og cellegiften kladribin og av autolog stamcelletransplantasjon (22-25). Vemurafenib er et medikament som inaktiverer muterte BRAF-proteiner, og kasuistiske meddelelser har vist lovende effekt ved Erdheim-Chesters sykdom (26). Lokal strålebehandling kan også forsøkes (27), men Erdheim-Chesters sykdom er mindre følsom for strålebehandling enn langerhanscellehistiocytose (28).

Vi valgte å påbegynne behandling med pegylert interferon- $\alpha, 180 \mu \mathrm{g}$ ukentlig, men på grunn av bivirkninger ble dosen redusert til $135 \mu \mathrm{g}$ ukentlig. Etter 22 måneders behandling med pegylert interferon- $\alpha$ har det ikke kommet nye organmanifestasjoner vurdert ved PET-CT, men pasienten er fremdeles plaget med smerter i fra skjelettet og vedvarende synsforstyrrelser og har nedsatt allmenntilstand. Det er påvist mutasjon $B R A F$ V600-genet hos pasienten og det vurderes å starte behandling med vemurafenib.

Pasienten har gitt samtykke til at artikkelen blir publisert.

\section{Øyvind Midtvedt (f. 1964)}

er spesialist i revmatologi og overlege.

Forfatter har fylt ut ICMJE-skjemaet og oppgir ingen interessekonflikter.

\section{Jan Tore Gran (f. 1949)}

er dr.med., spesialist i revmatologi, seksjonsoverlege og professor ved Universitetet i Oslo. Forfatter har fylt ut ICMJE-skjemaet og oppgir ingen interessekonflikter.

\section{Hanne Solheim (f. 1965)}

er spesialist i nukleærmedisin med spesialkompetanse på PET-CT. Hun er lege i spesialisering i radiologi.

Forfatter har fylt ut ICMJE-skjemaet og oppgir ingen interessekonflikter.

\section{Eva Kirkhus (f. 1960)}

er spesialist i radiologi og overlege. Forfatter har fylt ut ICMJE-skjemaet og oppgir ingen interessekonflikter.

\section{Signe Spetalen (f. 1970)}

er ph.d., spesialist i patologi og overlege. Forfatter har fylt ut ICMJE-skjemaet og oppgir ingen interessekonflikter.

Litteratur

1. Birch-Hirschfeld A. Zur Diagnostic and Pathologic der Orbital Tumoren. Bericht uber die Zusammenkunft der Deutschen Ophthalmologischen Gesellschaft 1905; 32: 127-35.

2. Chaudhry IA, Shamsi FA, Arat YO et al. Orbital pseudotumor: distinct diagnostic features and management. Middle East Afr J Ophthalmol 2008; 15: 17-27.

3. Rødahl E, Bertelsen T, Seland J et al. Svulster i orbita. Tidsskr Nor Lægeforen 2000; 120: 3518-23.

4. Chester W. Über Lipoidgranulomatose. Virchows Arch Pathol Anat 1930; 279: 561-6

5. Haroche J, Arnaud L, Amoura Z. Erdheim-Cheste disease. Curr Opin Rheumatol 2012; 24: 53-9.

6. Arnaud L, Gorochov G, Charlotte F et al. Systemic perturbation of cytokine and chemokine networks in Erdheim-Chester disease: a single-center series of 37 patients. Blood 2011; 117: 2783-90.

7. Veyssier-Belot C, Cacoub P, Caparros-Lefebvre D et al. Erdheim-Chester disease. Clinical and radiologic characteristics of 59 cases. Medicine (Baltimorel 1996: 75: 157-69.

8. Arnaud L, Malek Z, Archambaud F et al. 18F-fluorodeoxyglucose-positron emission tomography scanning is more useful in followup than in the initial assessment of patients with Erdheim-Ches ter disease. Arthritis Rheum 2009; 60: 3128-38.

9. Steňová E, Steňo B, Povinec P et al. FDG-PET in the Erdheim-Chester disease: its diagnostic and follow-up role. Rheumatol Int 2012; 32: 675-8.

10. Haroche J, Amoura Z, Dion E et al. Cardiovascula involvement, an overlooked feature of ErdheimChester disease: report of 6 new cases and a literature review. Medicine (Baltimore) 2004; 83: 371-92.

11. Brun AL, Touitou-Gottenberg D, Haroche J et al. Erdheim-Chester disease: CT findings of thoracic involvement. Eur Radiol 2010; 20: 2579-87.

12. Egan AJ, Boardman LA, Tazelaar HD et al. Erdheim-Chester disease: clinical, radiologic, and histopathologic findings in five patients with interstitial lung disease. Am J Surg Pathol 1999; 23: 17-26.

13. Alper MG, Zimmerman LE, Piana FG. Orbital manifestations of Erdheim-Chester disease. Trans Am Ophthalmol Soc 1983; 81: 64-85.

14. Al-Quran S, Reith J, Bradley J et al. ErdheimChester disease: case report, PCR-based analysis of clonality, and review of literature. Mod Pathol 2002; 15: 666-72

15. Chetritt J, Paradis V, Dargere D et al. Chester-Erdheim disease: a neoplastic disorder. Hum Pathol 1999: 30: 1093-6.

16. Haroche J, Amoura Z, Charlotte F et al. Imatinib mesylate for platelet-derived growth factor receptor-beta-positive Erdheim-Chester histiocytosis. Blood 2008; 111: 5413-5. 
17. Haroche J, Charlotte F, Arnaud L et al. High prevalence of BRAF V600E mutations in Erdheim-Chester disease but not in other non-Langerhans cell histiocytoses. Blood 2012; 120: 2700-3.

18. Braiteh F, Boxrud C, Esmaeli B et al. Successful treatment of Erdheim-Chester disease, a nonLangerhans-cell histiocytosis, with interferonalpha. Blood 2005; 106: 2992-4.

19. Haroche J, Amoura Z, Trad SG et al. Variability in the efficacy of interferon-alpha in ErdheimChester disease by patient and site of involvement: results in eight patients. Arthritis Rheum 2006; 54: $3330-6$

20. Hervier B, Arnaud L, Charlotte F et al. Treatment of Erdheim-Chester disease with long-term highdose interferon- $\alpha$. Semin Arthritis Rheum 2012: 41: $907-13$.

21. Arnaud L, Hervier B, Néel A et al. CNS involvement and treatment with interferon- $\alpha$ are independent prognostic factors in Erdheim-Chester disease: a multicenter survival analysis of 53 patients. Blood 2011; 117: 2778-82

22. Janku F, Amin HM, Yang D et al. Response of histiocytoses to imatinib mesylate: fire to ashes. J Clin Oncol 2010; 28: e633-6.

23. Aouba A, Georgin-Lavialle S, Pagnoux C et al. Rationale and efficacy of interleukin-1 targeting in Erdheim-Chester disease. Blood 2010; 116: 4070-6.

24. Myra C, Sloper L, Tighe PJ et al. Treatment of Erdheim-Chester disease with cladribine: a rational approach. Br J Ophthalmol 2004; 88: 844-7.

25. Boissel N, Wechsler B, Leblond V. Treatment of refractory Erdheim-Chester disease with double autologous hematopoietic stem-cell transplantation. Ann Intern Med 2001; 135: 844-5.
26. Haroche J, Cohen-Aubart F, Emile JF et al. Dramatic efficacy of vemurafenib in both multisystemic and refractory Erdheim-Chester disease and Langerhans cell histiocytosis harboring the BRAF V600E mutation. Blood 2013; 121: 1495-500.

27. Notter M, Kern T, Forrer A et al. Radiotherapy of pseudotumor orbitae. Front Radiat Ther Oncol 1997; 30: 180-91.

28. Miller RC, Villà S, Kamer $\mathrm{S}$ et al. Palliative treatment of Erdheim-Chester disease with radiotherapy: a Rare Cancer Network study. Radiother Oncol 2006; 80: 323-6.

Mottatt 24.1. 2013, første revisjon innsendt 4.6. 2013, godkjent 9.4. 2014. Redaktør: Merete Kile Holtermann. 